\section{Birokrasi di Era Revolusi Industri 4.0}

\section{(Studi Pelayanan Perijinan memulai Usaha di Indonesia)}

\section{Muhammad Syafiq}

Peneliti Pertama Lembaga

Administrasi Negara

Mahasiswa Magister Kepemimpinan

dan Inovasi Kebijakan UGM

Korespodensi Penulis. E-mail:

muhammadsyafiq.lan@gmail.com

\begin{abstract}
Abstrak
Indonesia saat ini sedang berupaya untuk menumbuhkan iklim investasi dengan memberikan kemudahan berusaha. Salah satu strategi yang dilakukan oleh pemerintah adalah dengan melakukan debirokratisasi dan digitalisasi pelayanan perizinan memulai usaha. Hal tersebut dilakukan dengan mendorong digitalisasi pelayanan perijinan terpadu satu pintu (PTSP) di Pemerintah Daerah (BKPM, 2016). Pergerakan yang dilakukan tersebut dalam rangka memenuhi nilai publik untuk menciptakan kecepatan dan kemudahan dalam berusaha di era revolusi industri 4.0. Namun demikian, langkah yang dilakukan oleh pemerintah tersebut tidak berdampak siginifikan terhadap capaian ease of doing business 2019 yang menempatkan Indonesia pada posisi 73 dari 190 negara di dunia. Capaian tersebut masih jauh dari target Presiden Jokowi yaitu pada peringkat 40 besar pada tahun 2017 . Artikel ini bertujuan untuk menjelaskan 2 (dua) hal yaitu: pertama, mengapa debirokratisasi yang dilakukan oleh pemerintah belum mampu memenuhi nilai birokrasi yang juga merupakan adaptasi nilai publik. Kedua,
\end{abstract}

bagaimana risk society dari adanya debirokratisasi dan digitalisasi pelayanan perizinan memulai usaha. Studi pada pelayanan perizinan memulai usaha dipilih untuk menggambarkan tujuan tersebut dengan menggunakan analisis literatur dan data sekunder. Hasil pembahasan dalam artikel ini menemukan bahwa arus besar elektronisasi dan pendirian PTSP tidak dibarengi dengan semangat penuh untuk menghilangkan silo mentality serta struktur hirarki yang panjang. Efisiensi dan efektivitas yang merupakan nilai birokrasi tidak dapat dipenuhi. Debirokratisasi dan digitalisasi mendorong munculnya usaha-usaha baru dan menciptakan iklim usaha yang lebih baik. Investasi akan meningkat karena iklim usaha yang bagus di Indonesia. Namun demikian, debirokratisasi dan digitalisasi menimbulkan dilema karena ada risiko negatif yang dapat ditimbulkan dari adanya kedua langkah tersebut.

Kata Kunci: Nilai Publik, Nilai Birokrasi, Debirokratisasi, Birokratisasi, Pelayann Perizinan

\section{Bureaucracy in the Industrial Revolution Era 4.0 \\ (Study on Licensing Services to start a business in Indonesia)}

\begin{abstract}
Indonesia is currently trying to foster an investment climate by providing ease of business. One of the strategies carried out by the government is to conduct bureaucratization and digitization of licensing services to start a business. This was done by encouraging the digitization of onestop integrated licensing services (PTSP) in the Local Government (BKPM, 2016). The movement was carried out in order to meet public
\end{abstract}


value to create speed and ease of doing business in the era of the industrial revolution 4.0. However, the steps taken by the government did not have a significant impact on the achievement of the ease of doing business in 2019 which placed Indonesia in position 73 of 190 countries in the world. This achievement is still far from President Jokowi's target, which is ranked in the top 40 in 2017. This article aims to explain 2 (two) things, namely: first, why the bureaucracy carried out by the government has not been able to meet the bureaucratic value which is also an adaptation of public values. Second, how is the risk society from the bureaucratization and digitization of licensing services to start a business. Studies on licensing services starting a business were chosen to illustrate these objectives using literature analysis and secondary data. The results of the discussion in this article found that the large flow of electrons and the establishment of PTSP was not accompanied by full enthusiasm to eliminate the silo mentality and the long hierarchical structure. Efficiency and effectiveness which are bureaucratic values cannot be fulfilled. Debureaucratization and digitalization encourage the emergence of new businesses and create a better business climate. Investment will increase due to the good business climate in Indonesia. However, debureaucratization and digitalization pose a dilemma because there are negative risks that can arise from the existence of both steps.

Keywords: Public Values, Bureaucracy Values, Debureaucratization, Bureaucratization, Licensing Services

\section{A. PENDAHULUAN}

Indonesia telah berhasil meningkatkan capaian ease of doing business dalam periode 5 (lima) tahun terakhir. Capaian ease of doing business (EoDB) Indonesia berhasil naik 41 peringkat yaitu dari peringkat 114 pada EoDB 2015 ke peringkat 73 pada EoDB 2019. Indonesia hanya turun 1 (satu) peringkat dalam capaian EoDB 2019. Secara detail capaian EoDB Indonesia dapat dilihat pada gambar 1.

Capaian tersebut tidak terlepas dari paket kebijakan ekonomi yang diambil oleh pemerintah. Dalam kurun waktu 4 (empat) tahun pemerintah JokowiJK mengeluarkan paket kebijakan 1-XVI. Paket kebijakan I, II, dan XII merupakan paket kebijakan yang paling berpengaruh terhadap capaian EoDB Indonesia. Paket kebijakan I fokus dalam mendorong daya saing industri dengan mengurangi dan menyederhanakan regulasi serta mempermudah birokrasi. Paket kebijakan II fokus pada promosi investasi dan devisa melalui pemberian kemudahan perizinan investasi 3 jam, dan insentif devisa hasil ekspor. 
Gambar 1. Capaian EoDB Indonesia 2015-2018

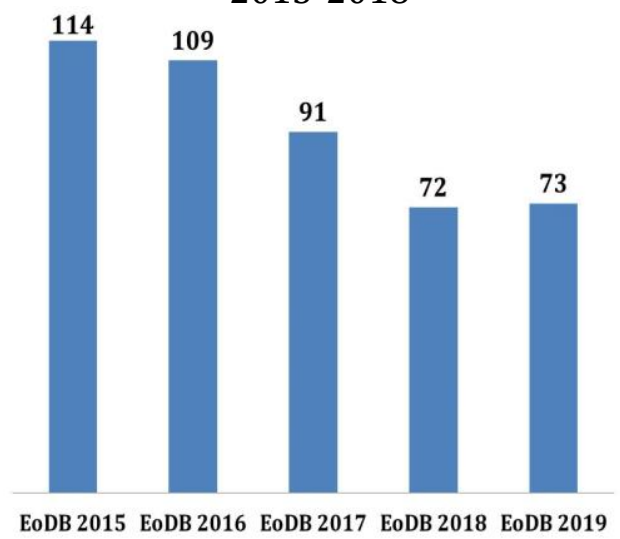

Catatan: Peringkat 1-190

Sumber: (World Bank, 2014, 2015, 2016, 2017, 2018)

Namun, capaian EoDB Indonesia masih jauh dari target presiden Jokowi. EoDB ditargetkan akan menempati posisi 40 besar pada tahun 2017 (https://finance.detik.com/beritaekonomi-bisnis/d4283755/peringkat-eodb-jauhdari-target-jokowi-darmin-inipekerjaan-besar). Selain itu, capaian tersebut juga masih konsisten tertinggal dari Negara lainnya di Asia Tenggara seperti Singapura, Malaysia, Thailand, Vietnam, dan Brunei Darussalam. Bahkan dalam kurun waktu 5 (lima) tahun terakhir, Singapura selalu berada pada peringkat 3 (tiga) besar.
Gambar 2. Peringkat EoDB 2015-2018

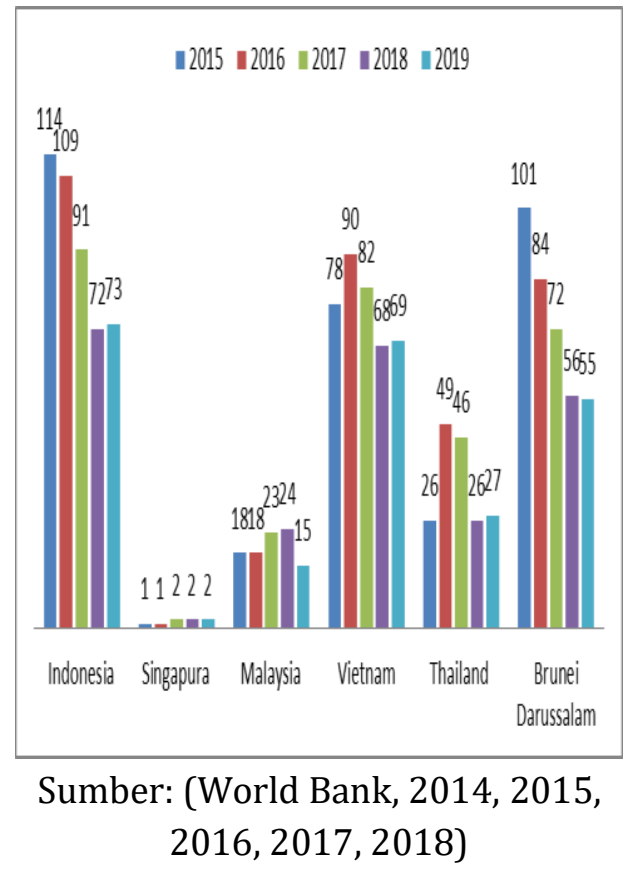

Lambatnya kenaikan peringkat EoDB Indonesia tersebut disebabkan karena adanya patologi birokrasi yang telah lama mengkungkung birokrasi Indonesia. Sehingga, debirokratisasi, deregulasi, dan digitalisasi yang dilakukan belum mampu dengan optimal menjalankan nilai birokrasi yang telah ditetapkan berdasarkan nilai publik yang berlaku utamanya terkait kecepatan dan kemudahan. Pelayanan perizinan masih melalui banyak prosedur dan waktu penyelesaian yang cukup lama. Silo Mentality, hierarki yang berlebihan serta formalisasi berlebihan menjadi patologi birokrasi yang menghambat proses reformasi pelayanan perijinan memulai usaha di Indonesia. Selain itu, proses debirokratisasi, deregulasi serta digitalisasi harus dihadapkan 
beberapa risk society seperti konflik apabila tidak dilakukan kajian yang matang.

\section{B. TEORI (Literature Review) \\ 1. Arus Pergeseran dari Manual Menuju Sistem Online}

Pelayanan perizinan yang diselenggarakan oleh pemerintah dahulu identik dengan mekanisme kerja yang manual. Pengguna layanan harus datang ke unit pelayanan perizinan dengan membawa berkas persyaratan yang tidak sedikit jumlahnya. Selain itu, masyarakat juga masih harus antri menunggu untuk dilayani oleh petugas. Kondisi tersebut saat ini sudah mulai mengalami pergeseran. Dari manual ke sistem online. Badan Koordinasi Penanaman Modal (BKPM) yang menjadi leading sektor pelayanan perizinan usaha akan menerapkan digitalisasi. Digitalisasi mekanisme baru penyelenggaraan layanan perizinan dilakukan dengan menerapkan tanda tangan digital yang tersertifikasi (Certified Digital Signature) pada penerbitan Izin Prinsip Penanaman Modal (IPPM) dengan format portable document format (PDF), yang dilengkapi dengan Lembar Pengesahan (https://www.wartaekonomi.co.i d/read143745/news_post.php).

Pemerintah daerah saat ini sedang masif membangun pelayanan perijinan menggunakan sistem online. Masyarakat tidak perlu lagi datang ke kantor pelayanan perizinan yang sebenarnya juga sudah dibangun tempat pelayanan perizinan terpadu. Berdasarkan data yang dikeluarkan oleh Badan Koordinasi Penanaman Modal (BKPM), 60 \% Unit Pelayanan Terpadu Satu Pintu (PTSP) di pemerintah daerah telah melakukan elektronisasi (BKPM, 2016).

Kota Bandung merupakan salah satu dari sekian banyak daerah yang telah menggunakan TI dalam pelayanan perizinan memulai usaha. Dalam kurun waktu 2015-2017, Kota Bandung mengeluarkan 2 (dua) program unggulan yaitu "Hay U" (satu sentuhan untuk kemudahan), serta "GAMPIL" (Gadget Mobile Aplication License). "Hay U" merupakan aplikasi berbasis website secara online yang telah dilengkapi dengan fasilitas tracking. Sehingga, pengguna layanan dapat memantau perkembangan layanan. Kota Bandung juga memanjakan pengguna layanan perizinan memulai usaha dengan aplikasi "GAMPIL" yang dapat diakses melalui smart phone. Surat izin yang diproses melalui sistem online apabila sudah jadi akan diantar ke rumah melalui jasa pengantar pos (Badan Pelayanan Perizinan Terpadu Kota Bandung, 2016). Kota Pontianak, Kota Surabaya dan Kota Makassar juga telah melakukan hal yang sama dengan Kota Bandung dalam 
pelayanan perizinan memulai usaha (catatan survei Indeks Local Government Capacity for Business Pusat Pembinaan Analis Kebijakan Lembaga Administrasi Negara)

Optimalisasi penggunaan IT dalam pelayanan perizinan tersebut telah berhasil menaikkan indeks ease of doing business di beberapa Negara seperti Singapura, Malaysia, Hongkong, Taiwan, dan Korea Selatan. Singapura menggunakan sebuah sistem yang disebut dengan Bizfile sebuah sistem berbasis internet mulai dari registrasi online, pengajuan dan pengambilan informasi. Sedangkan Korea Selatan mengenalkan online-one stop shop dan star biz. Capaian indeks ease of doing business beberapa Negara yang memanfaatkan IT tersebut secara konsisten jauh di atas Indonesia. Terutama Singapura yang selalu menempati 3 (tiga) besar dalam 5 (lima) tahun terakhir (Pusat kajian Reformasi Administrasi, 2016).

\section{Pergeseran Nilai Birokrasi: Birokratisasi Debirokratisasi}

Pergeseran paradigma administrasi Negara mulai dari old public administration (OPA), New Public management (NPM), serta New Public Service (NPS) ikut mewarnai pergeseran nilai birokrasi. Old Public
Administration banyak dipengaruhi oleh pandangan Max Weber tentang birokrasi ideal. Old Public Administration (OPA) menempatkan pemerintah sebagai sentral dalam penyelenggaraan pemerintahan. Guy Peter merangkum 6 (enam) prinsip yang dianut dalam paradigm OPA yaitu: 1) Pelayanan sipil bersifat apolitis; 2) Hirarki dan aturan; 3) Ketahanan dan stabilitas; 4) Layanan sipil yang terinstitusionalisasi; 5) Pengaturan internal; 6) Kesetaraan (internal dan eksternal untuk organisasi) (Peters, 2001 dalam Pfiffner, 2004). Paradigma tersebut muncul pada awal revolusi industri di mana pertarungan antar kelas terjadi antara kelas borjuis dan proletar, kelas pekerja dan pemilik modal. Paradigma tersebut muncul pada abad ke 19 untuk mengatasi administrasi patrimonial yang didominasi oleh patronase dan favouritisme dalam pengambilan keputusan(Pfiffner, 2004). Birokratisasi menjadi nilai yang menjadi dasar dalam penyelenggaraan pelayanan publik. Birokratisasi sendiri diartikan sebagai proses penerapan prinsip yang diajarkan oleh Weber dalam birokrasi yaitu hierarki, formalisasi, impersonalitas, serta spesialisasi (Dwiyanto, 2015). 
Gambar 3. Pergeseran Paradigma Administrasi Publik dan Nilai Birokrasi

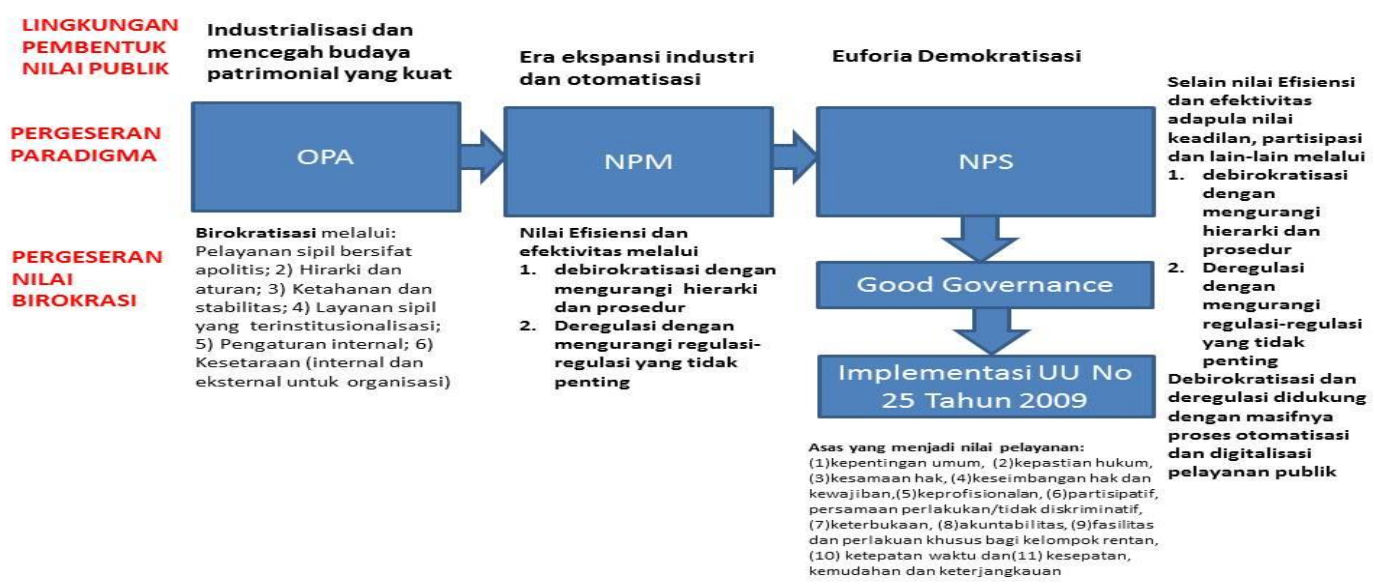

Pendekatan tersebut ternyata mendapatkan kritik karena tidak efektif dan efisien dalam mengatasi sebagala persoalan publik. Oleh karena itu, muncul kemudian adalah konsep yang disebut dengan New Public Management (NPM). Inti dari konsep tersebut adalah agar birokrasi pemerintah lebih efektif dan efisien, maka pengelolaannya harus mengadopsi mekanisme kerja sektor privat. NPM menjadi inspirasi dari gerakan yang disebut dengan reinventing government dan mendorong adanya desentralisasi kekuasaan ke bawah, standar prosedur operasi yang lentur, kreativitas dan inovasi, jenjang kekuasaan yang flat, serta sistem kepegawaian yang lebih terbuka dan kompetitif (Osborne dan Plastrik, 1997 dalam Dwiyanto, 2015). Efektivitas dan efisiensi yang menjadi tuntutan publik waktu itu menjadi prinsip yang benar-benar dipegang teguh.
Paradigma NPM juga memunculkan banyak kritik karena cenderung mengabaikan unsur-unsur seperti keadilan, dan humanisme. Hal tersebut kemudian yang menjadi pendorong munculnya pendekatan New Public Service (NPS). Pendekatan NPS dipengaruhi oleh teori tentang citizenship, community and civil society, organizational humanists, and post modern administrationalists. Dalam pendekatan NPS, stakeholder dalam pengambilan kebijakan semakin bervariatif. Bahkan dalam paradigma tersebut terdapat konsep governance yaitu integrasi antara pemerintah, civil society, dan sektor privat. Nilai yang dibangun juga tidak terbatas pada efisiensi dan efektivitas namun terdapat nilai lainnya seperti keadilan, partisipasi, dan lain-lain (Denhardt \& Dehardt, 2000). Good governance merupakan salah satu konsep pengelolaan pemerintah yang masuk dalam paradigma ini. 
Vol.1 No.1 Juni 2019

Beberapa nilai dalam good governance diantaranya berorientasi pada konsensus bersama, akuntabilitas, partisipasi, mengikuti aturan hukum, efektif dan efisien, responsif, transparansi, kesamaan dan inklusif (Singh et al., 2009).

Pelayanan publik di Indonesia termasuk di dalamnya pelayanan perizinan memulai berusaha berusaha mengadopsi prinsip good governance melalui Undang-undang nomor 25 Tahun 2009 pasal 4 tentang pelayanan publik. Beberapa asas dalam pelayanan publik dalam rezim UU tersebut adalah kepentingan umum, kepastian hukum, kesamaan hak, keseimbangan hak dan kewajiban, keprofisionalan, partisipatif, persamaan perlakukan/tidak diskriminatif, keterbukaan, akuntabilitas, fasilitas dan perlakuan khusus bagi kelompok rentan, ketepatan waktu dan kesepatan, kemudahan dan keterjangkauan. Asas tersebut dijadikan sebagai nilai dalam birokrasi pelayanan perizinan untuk melakukan debirokratisasi, dan deregulasi.

Debirokratisasi dan deregulasi mulai disuarakan dalam periode NPM dan diteruskan pada periode NPS. Debirokratisasi merupakan upaya untuk meminimalisasi aturan-aturan. Bahkan dalam tingkatan yang lebih ekstrim, adanya penyerahan fungsi dan kegiatan ke organisasi lain dengan alasan efisiensi dan efektivitas (Eisenstadt, S, 1959). Sedangkan deregulasi merupakan sebuah proses meminimalisasi regulasi-regulasi yang menghambat kerja birokrasi. Konsep deregulasi muncul pertama kali di US untuk merespon pasar ekonomi global guna memperluas cakupan industrialisasi dan otomatisasi (Howitz, 1986). Selain itu, arus besar digitalisasi dan otomatisasi juga menjadi pendukung langkah debirokratisasi dan deregulasi yang dilakukan pemerintah utamanya di era revolusi industri 4.0 .

\section{METODE}

Penelitian ini bersifat kualitatif menggunakan metode desk-research. Metode deskresearch (penelitian kepustakan) menggunakan sumber-sumber yang tersedia di publik, seperti media elektronik, surat kabar, buku, laporan riset, dan jurnal. Nantinya, metode ini menganalisis dengan landasan teori yang relevan.

\section{HASIL DAN PEMBAHASAN}

1. Patologi Birokrasi dan Hambatan Debirokratisasi Pelayanan Perijinan Memulai Usaha

Reformasi birokrasi pelayanan perizinan memulai usaha dengan paket kebijakan yang dikeluarkan pada hakikatnya melalui 3 (tiga) strategi yaitu deregulasi, debirokratisasi, serta 
penegakan hukum dan kepastian usaha. Deregulasi dilakukan dengan melakukan rasionalisasi peraturan dengan menghilangkang duplikasi, penyelarasan dan konsistensi peraturan. Debirokratisasi dilakukan dengan penyederhaan dan pemberian kemudahan perzinan, optimalisasi Pelayanan Terpadu Satu Pintu (PTSP), serta pelayanan perizinan melalui sistem elektronik. Penegakan hukum dan kepastian usaha dilakukan melalui penyelesaian permasalahan regulasi dan birokrasi, pemberantasan pungutan liar, serta pemberian sanksi yang tegas dan tuntas (Pusat kajian Reformasi Administrasi, 2016).

Pemerintah melalui BKPM mengejawantahkan strategi debirokratisasi, deregulasi dan penegakan hukum dan kepastian usaha melalui optimalisasi PTSP. Pertama, BKPM mengintegrasikan pelayanan perizinan di 22 Kementerian/lembaga dalam satu lokasi. Kedua, mendelegasikan 162 perizinan kepada BKPM. Keempat, mendirikan $\quad 90 \quad \% \quad$ PTSP $\quad$ di Pemerintah daerah. Kelima, mewujudkan 61 \% PTSP daerah untuk mengimplementasikan perizinan secara elektronik. Ketujuh, menerbitkan 17.238 perizinan dan fasilitas pada tahun 2015. Kedelapan, menciptakan layanan perizinan 3 (tiga) jam (BKPM, 2016).

Segala langkah yang dilakukan oleh pemerintah tersebut ternyata tidak dapat secara signifikan meningkatkan peringkat ease of doing business Indonesia karena tidak mampu mengimplementasikan nilai efisiensi dan efektivitas secara optimal. Indikator dari hal tersebut adalah banyaknya prosedur dan persyaratan serta lama waktu penyelesaian perizinan memulai usaha. Setiap calon pengusaha harus melalui sebelas prosedur untuk mengurus perizinan melalui usaha. Prosedur perizinan pelayanan perizinan memulai usaha tersebut menjadi kewenangan pemerintah pusat dan pemerintah daerah. Ironisnya, setiap prosedur memerlukan persyaratan yang banyak. Guna melalui prosedur pembuatan akta pendirian perusahaan contohnya, harus memenuhi 16 (enam belas) persyaratan. Selain itu, terjadi duplikasi dan pengulangan persyaratan khususnya Kartu Tanda Penduduk (KTP) yang ditemukan di seluruh prosedur (Pusat kajian Reformasi Administrasi, 2016). Secara detail hal tersebut dapat dlihat pada tabel 1 . 
Vol.1 No.1 Juni 2019

Tabel 1. Prosedur dan Persyaratan Perizinan Memulai Usaha

\begin{tabular}{|c|c|c|}
\hline No & Prosedur & $\begin{array}{l}\text { Jumlah } \\
\text { Persyaratan }\end{array}$ \\
\hline \multicolumn{3}{|c|}{ Pemerintah Pusat } \\
\hline 1 & $\begin{array}{l}\text { Pendaftaran } \\
\text { nama } \\
\text { perusahaan }\end{array}$ & 12 \\
\hline 2 & $\begin{array}{l}\text { Pembuatan akta } \\
\text { pendirian } \\
\text { perusahaan }\end{array}$ & 16 \\
\hline 3 & $\begin{array}{l}\text { Pengesahan } \\
\text { status badan } \\
\text { hukum }\end{array}$ & 2 \\
\hline 4 & $\begin{array}{l}\text { Pembayaran } \\
\text { penerimaan } \\
\text { bukan pajak } \\
\text { (PNBP) }\end{array}$ & 4 \\
\hline 5 & $\begin{array}{l}\text { Pendaftaran dan } \\
\text { pengumuman } \\
\text { perseroan } \\
\text { terbatas dalam } \\
\text { berita Negara }\end{array}$ & 6 \\
\hline 6 & $\begin{array}{l}\text { Pendaftaran } \\
\text { NPWP }\end{array}$ & 4 \\
\hline 7 & \begin{tabular}{l}
\multicolumn{2}{l}{ Pendaftaran } \\
wajib lapor \\
ketenaga \\
kerjaan di \\
perusahaan
\end{tabular} & 8 \\
\hline 8 & $\begin{array}{l}\text { Pendaftaran } \\
\text { BPJS } \\
\text { Ketenagakerjaan }\end{array}$ & 6 \\
\hline \multicolumn{3}{|c|}{$\begin{array}{l}\text { Pemerintah } \\
\text { Bandung) }\end{array}$} \\
\hline 9 & SIUP & 9 \\
\hline 10 & TDP & 8 \\
\hline
\end{tabular}

Sumber: (Pusat kajian Reformasi Administrasi, 2016)

\section{Pelayanan perizinan} memulai usaha masih tergolong lama khususnya untuk memenuhi prosedur di luar PTSP. Sebagai contoh, untuk mengurus pendaftaran nama perusahaan dan pembuatan akta pendirian perusahaan di notaris membutuhkan waktu rata-rata lebih dari 2 (dua) minggu. Untuk pengurusan SIUP dan TDP yang prosesnya di PTSP, rata-rata daerah mampu memberikan pelayanan dalam waktu 1-7 hari. Sebagai contoh, Pemerintah Kota Bandung yang dapat menyelesaikan proses permohonan SIUP dan TDP dalam waktu 7 (tujuh) hari. Meskipun demikian, jika dibandingkan dengan Negara lain, capaian daerah di Indonesia masih tergolong karena Negara seperti Singapura telah mampu memberikan layanan dalam hitungan jam (Pusat kajian Reformasi Administrasi, 2016).

Kegagalan debirokratisasi, deregulasi dan digitalisasi disebabkan karena birokrasi weberian benar-benar sudah mengakar. Silo mentality dan hierarki berlebihan sebagai dampak proses birokratisasi yang berlangsung lama kemudian menimbulkan beberapa hambatan. Silo Mentality menyebabkan penyerahan kewenangan ke PTSP tidak sepenuhnya dilakukan. Beberepa perizinan tidak diberikan kepada PTSP terutama izin teknis. Sehingga pengguna pelayanan masih harus berhubungan dengan banyak unit layanan meskipun sudah didirikan PTSP. 
Gambar 4. Alur Hierarki Pelayanan Perizinan di BPPT Pemerintah Kota Bandung

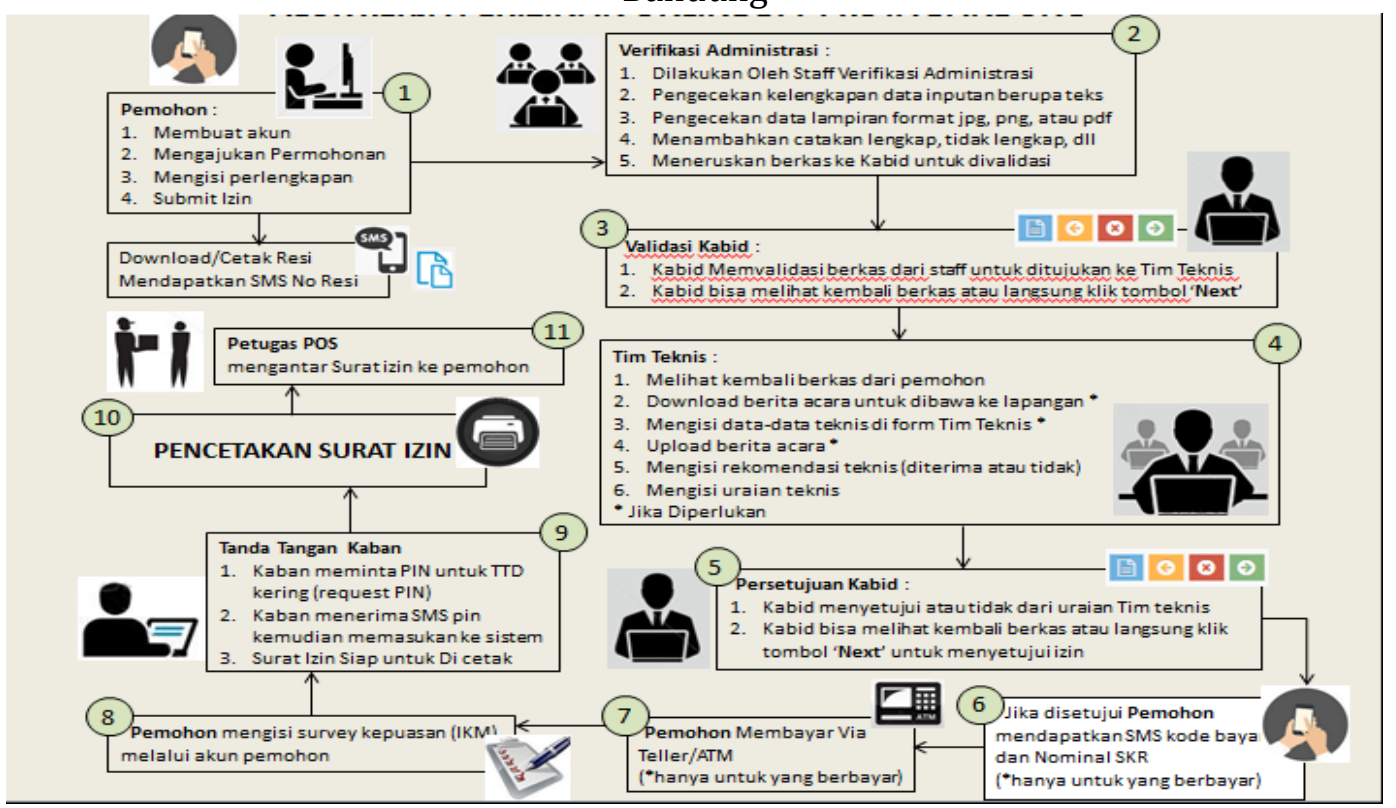

Sumber: BPPT Pemerintah Kota Bandung, 2016

Hierarki yang berlebihan menjadi salah satu akar masalah dari kegagalan debirokratisasi dan digitalisasi pelayanan perizinan memulai usaha. Hierarki membuat proses pelayanan perizinan membutuhkan waktu yang lebih lama. Digitalisasi kemudian tidak mampu memutus garis hierarki tersebut. Sebagai contoh, Pemerintah Kota Bandung yang telah menerapkan proses digitalisasi membutuhkan waktu 7 (tujuh) hari untuk menyelesaikan proses perizinan sedangkan Pemerintah Kota Tangerang Selatan yang belum menerapkan digitalisasi hanya membutuhkan waktu 1 (satu) hari (Pusat kajian Reformasi Administrasi, 2016). Hal tersebut disebabkan karena adanya proses verifikasi berjenjang yang prosesnya harus melalui hierarki yang juga panjang. Kondisi tersebut dapat dilihat pada gambar 4.

\section{Risk Society: Dilema Debirokratisasi dan Digitalisasi}

Teori tentang risk society dikenalkan Ulrich Beck yang menggambarkan proses perubahan sosial pasca industrialisasi. Menurutnya, telah terjadi perubahan dari modernitas lama ke arah modernitas lanjut. Individu pada masa modernitas lanjut akan semakin sulit untuk memprediksi kondisi masa depannya karena penuh dengan risiko dan ketidakpastian yang besar. Dalam kondisi masyakat risiko, individu akan terus berjuang untuk meminimalisir risiko untuk memperoleh kemanan dan kepastian. Jenis-jenis risiko 
yang biasanya muncul adalah risiko bencana alam, kemiskinan, akses pendidikan dan lain-lain (Beck, 1992 dalam Sutopo \& Meiji, 2014)

Selain itu, beck juga menjelaskan bahwa dalam masyarakat risiko, kehidupan semakin terindividualisasi. Artinya tenggung jawab dalam kehidupan sosial akan berada pada individu. Oleh karena itu, setiap individu haru memiliki perencanaan dalam pendidikan atau pekerjaan (Beck, 1992 dalam Sutopo \& Meiji, 2014).

Berbicara dalam konteks proses debirokratisasi dan digitalisasi pelayanan perizinan yang masif dilakukan, tentunya akan banyak hal positif yang dapat didapatkan. Peringkat ease of doing business Indonesia tentunya akan naik. Iklim investasi di Indonesia akan tumbuh dengan cepat karena adanya kepercayaan dari pelaku bisnis. Selain itu, kemudahan dalam perizinan akan memunculkan usaha-usaha baru. Khusus untuk digitalisasi, apabila Indonesia telah selesai dengan beberapa patologi birokrasinya, maka proses digitalisasi akan berjalan dengan optimal. Digitalisasi memungkinkan proses perizinan semakin cepat dalam hitungan jam bahkan menit.

Kemudahan berusaha di suatu negara sangat berdampak positif terhadap iklim investasi dan dunia usaha. Image positif yang terjadi akan mendorong pengusaha luar negeri untuk melakukan investasi di Indonesia. Usaha-usaha baru diharapkan juga akan muncul, utamanya perusahaan dengan skala Usaha Mikro Kecil dan Menengah (UMKM) yang padat karya. Hal tersebut terbukti pada awal implementasi debirokratisasi dan digitalisasi yaitu periode 20152016, penanaman modal asing naik 19,2 \%, penanaman modal dalam negeri naik $15 \%$, realisasi investasi naik 17,8\%, serta penyerapan tenaga naik 0,3\% (lihat gambar 6). Tentunya trend positif tersebut akan terus berlanjut apabila debirokratisasi dan digitalisasi pelayanan perizinan dapat lebih optimal dilakukan.

\section{Gambar 5. Realisasi Investasi} Indonesia 2014-2015

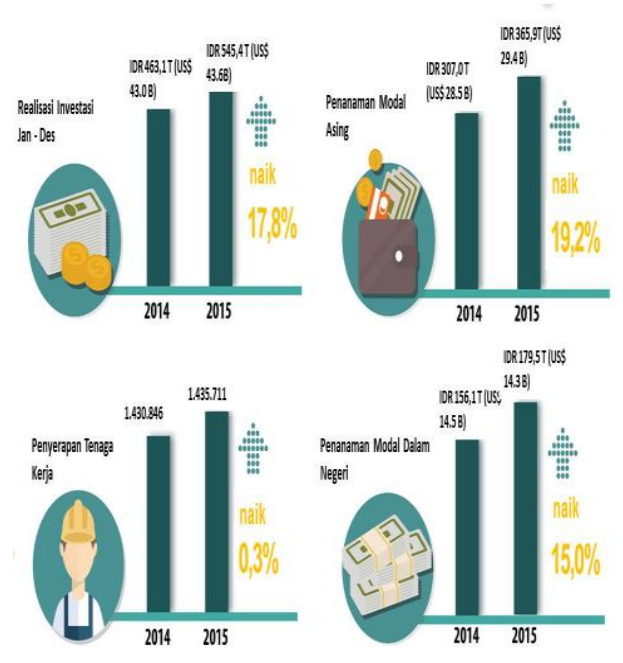

Sumber: BKPM, 2016

Namun demikian, proses debirokratisasi dan digitalisasi juga dapat menimbulkan risiko. 
Sebelum menjelaskan tentang risiko tersebut, perlu terlebih dahulu dipahami bahwa proses birokratisasi memiliki dampak positif dan negatif. Caiden (Caiden, 2009 dalam Dwiyanto, 2015) melalui teori parabolic yang dikembangkan mengungkapkan bahwa proses birokratisasi memiliki hubungan yang tidak liner namun parabolik dengan efisiensi. Birokratisasi pada titik tertentu akan menciptakan keetaraturan kerja. Namun, apabila telah melampui batas optimumnya maka birokrasi cenderung akan semakin tidak efisien dan lambat. Secara detail gambaran teori tersebut dapat dilihat pada gambar 6 .

Gambar 6. Teori parabolik Birokratisasi

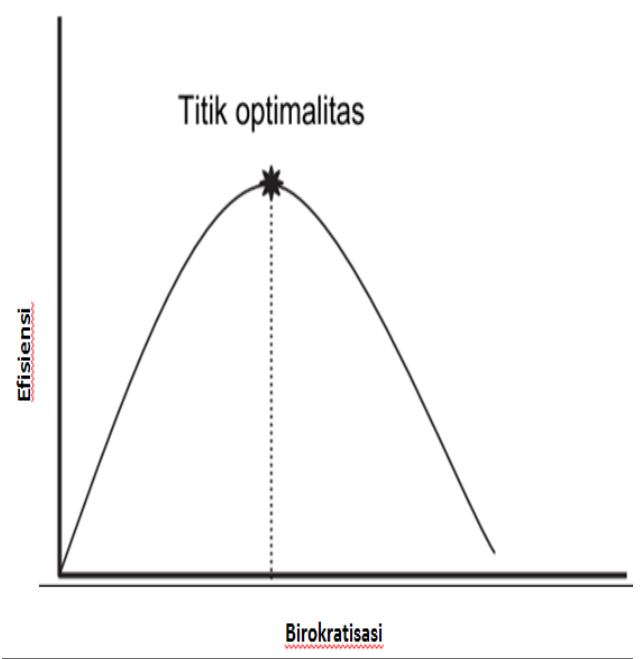

Sumber: (Caiden, 2009 dalam Dwiyanto, 2015)

Teori parabolik tersebut menjelaskan bahwa proses debirokratisasi untuk memangkas prosedur birokratisasi harus berdasarkan kajian yang matang. Debirokratisasi dilakukan apabila sudah melampui batas optimum birokratisasi. Proses debirokratisasi yang tidak tepat akan beresiko mengubah keteraturan. Sebagai contoh penghapusan HO yang dilakukan oleh pemerintah pusat mendapatkan penolakan dari beberapa pemerintah daerah karena akan berpotensi menimbulkan konflik dalam masyarakat. Pendirian usaha tanpa HO berarti belum ada kepastian persetujuan dari lingkungan sekitar. Contoh lainnya adalah pemangkasan hierarki secara berlebihan akan mengurangi kontrol terhadap proses pelayanan perizinan. Digitalisasi juga memberikan konsekuensi bahwa masyarakat calon pengguna layanan harus benar-benar melek digital. Bagi masyarakat yang tidak familiar dengan proses digital akan kesulitan dalam mengakses layanan. Kondisi tersebut terjadi di Kota Bandung, meskipun proses pelayanan sudah menggunakan sistem online, ternyata masih banyak pengguna layanan yang datang ke Kantor BPPT Kota Bandung karena tidak familiar dengan proses online (Pusat Kajian Reformasi Administrasi, 2016).

$$
\text { Iklim investasi dan }
$$

kemunculan usaha baru sebagai akibat kemudahan berusaha juga berpotensi menimbulkan kesenjangan ekonomi. Hal tersebut 
terjadi apabila tidak dibarengi dengan upaya pemberdayaan dan penguatan kapasitas SDM di Indonesia. Kemunculan usahausaha baru seharusnya mampu menggerakkan ekonomi masyarakat dan utamanya dapat mengurangi angka kemiskinan.

\section{E. SIMPULAN DAN SARAN}

Debirokratisasi dan digitalisasi pelayanan perizinan sedang menjadi arus besar pelayanan perizinan memulai usaha di Indonesia. Hierarki yang panjang, prosedur yang berbelitbelit mulai dipangkas. Pemerintah daerah berlomba-lomba menciptakan aplikasi dan sistem perizinan online. Namun hal tersebut ternyata tidak berdampak besar pada capaian ease of doing business di Indoensia karena birokrasi weberian telah mengakar dan menimbulkan silo mentality dan hierarki yang sulit dipangkas. Patologi birokrasi tersebut membuat proses digitalisasi tidak dapat berpengaruh banyak. Debirokratisasi dan digitalisasi sebenarnya dapat berpengaruh positif terhadap iklim usaha di Indonesia. Akan muncul usahausaha baru dan akan terjadi kepercayaan investasi di Indonesia. Namun, proses debirokratisasi dan digitalisasi pelayanan perizinan juga menimbulkan beberapa risiko ketidak teraturan dan potensi konflik antar masyarakat apabila tidak dilakukan dengan kajian mendalam. Kualitas kontrol terhadap dunia usaha akan turun apabila tidak dilakukan dengan kehati-hatian. Digitalisasi juga menuntut adanya peningkatan kualitas SDM masyarakat agar dapat mengakses layanan dengan baik. Terakhir, pertumbuhan iklim investasi dan usaha-usaha baru sebagai akibat kemudahan pelayanan perizinan yang ditawarkan berpotensi memunculkan kesenjangan apabila tidak dibarengi dangan perbaikan kualitas SDM.

\section{DAFTAR PUSTAKA}

BPPT Kota Bandung, 2016. Bahan paparan pelayanan publik di Badan Pelayanan Perizinan Terpadu Kota Bandung disampaikan saat kunjungan Tim Peneliti Lembaga Administrasi Negara 2016

BKPM, 2016. Bahan paparan dengan judul kebijakan penyederhanaan perizinan di bidang penanaman modal disampaikan di LAN tanggal 22 Juni 2016

Denhardt, R. B., \& Dehardt, J. V. (2000). The New Public Service: Serving Rather Than Steering. Public Administration Review, 60(6), 549-559.

Dwiyanto, A. (2015). Reformasi Birokrasi Birokrasi Kontekstual.

Eisenstadt, S, N. (1959). Bureaucracy, 
Bureaucratization, and Debureaucratization.

Administrative Science

Quarterly, 4(3), 302-320. https://doi.org/10.1007/sl 0551-008-9945-3

Howitz, R. B. (1986). Understanding

Deregulation. Theory and Society, 15(1/2 Special Double Issue: Structures of Capital (Jan., 1986)), 139174.

Pfiffner, J. P. (2004). Traditional

Public Administration versus The New Public Management: Accountability versus Efficiency. Institutionenbildung in Regierung und Verwaltung.

Pusat kajian Reformasi Administrasi. (2016). Kajian Pengukuran Indeks Kompleksitas Pelayanan Publik.

Singh, D., Nafees A. Ansari, N. A., \& Singh, S. (2009). GOOD GOVERNANCE \& IMPLEMENTATION IN ERA OF GLOBALIZATION. Indian Political Science Association, 70(4), 1109-1120.

Sutopo, O. R., \& Meiji, N. H. P. (2014). TRANSISI PEMUDA DALAM MASYARAKAT RISIKO: ANTARA ASPIRASI, HAMBATAN DAN KETIDAKPASTIAN Oki Rahadianto Sutopo Nanda Harda Pratama Meiji. Jurnal Universitas Paramadina, Vol. 11.
Wold Bank, 2014. Laporan Ease of Doing Business 2015

World Bank, 2015. laporan ease of Doing Business 2016

World Bank,2016. Laporan ease of Doing Business 2017

world Bank, 2017.laporan ease of doing business 2018

World Bang, 2018. Laporan ease of doing business 2019

https://finance.detik.com/beritaekonomi-bisnis/d4283755/peringkat-eodbjauh-dari-target-jokowidarmin-ini-pekerjaan-besar https://www.wartaekonomi.co.i d/read143745/news_post. php 